
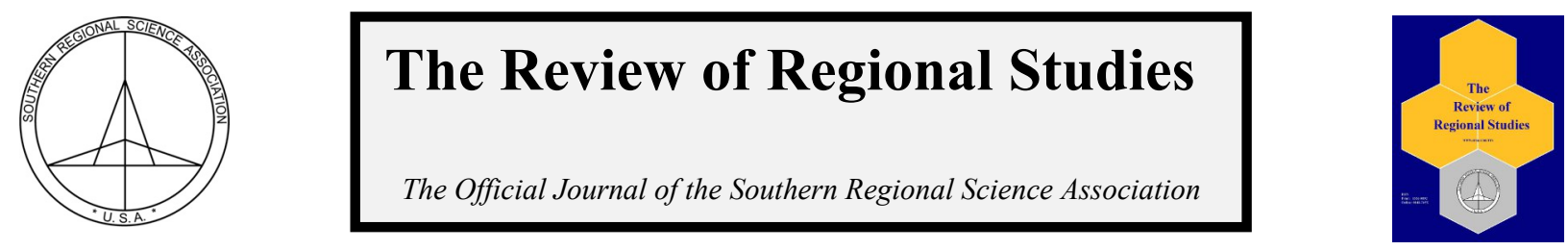

\title{
If You Build it, Will They Come?: Fiscal Federalism, Local Provision of Public Tourist Amenities, and the Vision Iowa Fund
}

\author{
Deepak Premkumar, Austin Quackenbush, Georgeanne Artz, and Peter Orazem
}

Department of Economics, Iowa State University, USA

\begin{abstract}
Iowa provided partial state funding to communities to build tourist attractions, a potential solution to local under-provision of public goods. A 10 percent increase in state funds increased county taxable retail sales by 0.1 percent. The State's return from resulting sales tax revenue averaged 11.8 percent. Local communities paid more and received less tax, and so their return was much smaller at 1.2 percent. Neighboring community sales also increased. The positive spillovers to neighbors and the state suggest that local communities will undersupply public amenities without state subsidies.
\end{abstract}

Keywords: amenities, fiscal federalism, sales tax, externalities, public goods, local government, spillovers JEL Codes: $\mathrm{H} 2, \mathrm{H} 4, \mathrm{H} 7$

Daddy, we don't have to sell the farm. People will come...from all over. They'll just decide to take a vacation, see? And they'll come to lowa City. They'll think it's really boring. So they'll want to pay us. Like buying a ticket. It will be just like when they were kids, a long time ago.

-Karin Kinsella to her father Ray, Field of Dreams (1989)

\section{INTRODUCTION}

Research documenting a variety of positive effects of amenities in fostering economic growth has sparked a burgeoning interest in amenity-led rural development efforts (Power, 2006). Most directly, amenities may spur tourism, which supports increased retail expenditures, employment and new firm entry. They may also draw new residents and new workers to the area (Deller et al. 2001; McGranahan 1999; Nord and Cromartie 1997).

While much of the research focus has been on natural amenities - pleasant climates, oceans, lakes, and other beautiful landscapes - more recent studies recognize the importance of man-made features as well. Built amenities such as recreation facilities can complement natural ones, resulting in stronger growth impacts than would occur from the natural ones alone (Olfert and Partridge, 2010). Cultural amenities such as museums or music venues contribute to local quality of life and encourage in-migration (Clark 2003; Florida 2002; Partridge, et al. 2008; Wojan, Lambert, and McGranahan 2007).

\footnotetext{
* We thank Liesl Eathington for help in locating and organizing the data used in this study and Kevin Kimle for comments. Premkumar and Quackenbush are undergraduate students, Artz is Assistant Professor, and Orazem is University Professor of Economics at Iowa State University, Ames, IA. Corresponding Author: G.M. Artz E-mail: gartz@iastate.edu
}

(C) Southern Regional Science Association 2014.

ISSN 1553-0892, 0048-749X (online)

www.srsa.org/rrs 
A long-standing issue in public economics is whether local communities will provide the optimal level of such public built amenities. If benefits from these local public goods spill over to nonresidents (Gordon, 1983), or if funding for the amenity is generated by distortionary local taxes (Zodrow and Mieszkowski 1986), the local government will under-invest in local public goods relative to the optimal level. One way to increase the supply of local public goods is for higher levels of government to provide matching grants. When appropriately designed, these matching grants can induce local governments to incorporate the interjurisdictional spillover benefits in their decision making, lessening the costs arising from a lack of coordination among communities, while preserving local decision-making authority (Gordon 1983; Oates 1999; Oates 2005).

Of course, there is no guarantee that such projects actually pay off. Many local projects may not be public goods. Others may crowd out sales in neighboring localities or not generate sufficient new revenue to justify their expense. Numerous studies have examined the public return to investments in expensive local amenities such as sports facilities, cultural centers and convention centers. Most convention centers have failed to generate expected revenues (Sanders, 2002). The main beneficiaries from professional sports arenas have been players and owners (Swindell and Rosentraub, 1998; Siegfried and Zimbalist, 2002). Gains from ticket sales often come at the expense of other entertainment venues, limiting the net return to these projects. However, not all large public amenity investments have been losers. Nelson (2001) found larger external benefits when new sports venues are placed in blighted areas. Rosentraub (2009) argues that nonpecuniary benefits from civic pride or from an enhanced reputation for entertainment can justify the investment, even when the pecuniary returns are lacking.

These studies have focused on large cities with many entertainment options to a new sports venue, convention site, or performing arts center. In those markets, it is likely that increased business in the new venue will come at the expense of competing entertainment options. Smaller towns may not have as many substitutes for the new venue. Consistent with that presumption, there is more evidence of positive pecuniary returns to minor league sports (Agha, 2013) and collegiate athletics (Lentz and Laband, 2009). With few competing entertainment options, the spillover benefits to the retail and hospitality industries will be more apparent. Similarly, in blighted areas of cities, there will be few competing entertainment options whose sales would be harmed by the new venue.

This study examines whether an Iowa state program that offered partial investment in local public cultural, recreational and entertainment amenities paid off for the state. In 2001, Iowa instituted Vision Iowa, a program that provided partial funding to Iowa communities for a wide variety of projects ranging from relatively small aquatic centers, park improvements and libraries to large convention centers and performance and sports arenas. Over eight years, the \$228 million public investment by Vision Iowa helped spur almost \$2 billion in new public facilities and improvements in 91 of the 99 counties in Iowa.

We find that the Vision Iowa program significantly raised taxable sales relative to past county-specific trend growth in sales in the counties that built new public amenities. The State of Iowa made an 11.8 percent net return per year on their investment in the form of a 5 percent sales tax on every additional dollar of sales generated. Neighboring counties also experienced more modest but statistically significant growth in taxable sales relative to trend. Therefore, we find two ways that benefits from the local amenities spilled over to other jurisdictions, implying that local governments would have undersupplied these built amenities without the state subsidy. The

(C) Southern Regional Science Association 2014. 
communities that hosted the new amenities had a much more modest 1.2 percent per year net return on their investments in the form of induced increase in local sales taxes, but they also received the utility from having the new amenities in town.

\section{CONCEPTUAL FRAMEWORK}

Tiebout (1956) argued that variation in the provision of local public goods and tax rates allowed people to "vote with their feet." Mobile residents choose to live in the community that offers a package of government services most closely aligned with their preferences an willingness to pay for those services. An implication is that communities can compete for residents by providing a mix of publicly funded amenities that is particularly attractive to populations it wishes to attract. These public goods will raise the value of inelastically supplied local land as migrants attracted by the amenities bid up land values. ${ }^{1}$ Because property tax receipts rise with rising land values, the property tax can be viewed as a residential user fee on efficiently-provided local public goods (Hamilton, 1975, 1976). In fact, Glaeser (1996) contends that it is the opportunity to raise local taxes that provides an incentive for local governments to provide the amenities that local residents desire.

Other researchers have argued that local governments are unlikely to provide the efficient level of local public goods. Zodrow and Mieszkowski (1986) and Zodrow (2006) showed that because property taxes increase the cost of private capital, investors will shift their capital investments toward low tax jurisdictions. Knowing that, local governments will hold back on the provision of public services relative to the level they would provide if they had access to a revenue source that did not distort the cost of capital. Gordon (1983) proposed that if local public goods generate positive spillovers to other jurisdictions, then local public good provision will be inefficient. For example, a local library can have positive spillovers to nonresidents who use the library but do not pay to support it, causing a local government to underinvest in its library. ${ }^{2}$

Gordon $(1983)$ and Oates $(1999,2005)$ argue that fiscal federalism offers a mechanism to induce the optimal level of public goods provision in the presence of these capital price distortions and positive spillovers. State or federal matching grants can induce additional investment in local public goods when local governments have an incentive to under-invest. The rationale for these multilevel funding methods presumes positive spillover benefits from public goods (Pereira and Roca-Sagalés, 2003; Pinto, 2007). ${ }^{3}$ This view of positive spillover benefits holding broadly for a variety of public goods is reflected in how the theory of fiscal federalism has been put in practice in numerous settings: Medicare, welfare reform, school finance, job training, public transit, disaster relief, and public housing.

\section{THE VISION IOWA PROGRAM}

In 2001, the State of Iowa instituted Vision Iowa, a program intended to enhance local recreational, cultural, educational, or entertainment attractions available to the general public.

\footnotetext{
${ }^{1}$ As noted by Bewley (1981), the conditions necessary to generate the Tiebout result are unlikely to hold in reality.

${ }^{2}$ There could be overprovision of local library services as well. Zax (1988) argues that if there are returns to scale in library provision, jurisdictions may each provide a library at less than efficient scale and higher cost rather than having one jurisdiction specialize in library provision.

${ }^{3}$ Boarnet (1998), Holl (2004), Shirley and Winston (2004) and Cohen and Morrison Paul (2007) present the alternate case in which centralized highway infrastructure investments cause negative spillovers. Local road improvements draw economic activity away from areas that do not receive the benefit of federal highway spending.
}

(C) Southern Regional Science Association 2014. 
Iowa communities could apply for state funding for a wide variety of projects. The program was funded by taxes imposed on casinos. ${ }^{4}$ Vision Iowa only provided partial funding for the projects, averaging 20 percent of the total cost. The balance had to be raised by the local government or through grants and charitable donations. This infusion of central funding to induce local effort is the essence of the fiscal federalism model.

This study examines whether Vision Iowa actually succeeded in generating economic benefits that justified its costs and whether any benefits were captured by the state or local level of government. It also investigates whether investments in one locality generated positive or negative spillovers in neighboring communities. Iowa is a good laboratory for evaluating such policies because the state is divided into 99 counties of roughly equal size, few of which have naturally occurring amenities that might complicate the identification of any returns to manmade amenities.

Funded projects were selected by a Vision Iowa Board charged with evaluating projects on their potential to improve a community's ability to attract new residents through improved quality of life, ability to attract visitors through improved attractions, or ability to generate an economic impact. Between 2001 and 2008, the \$228 million public investment by Vision Iowa helped spur almost $\$ 2$ billion in new public facilities and improvements through 393 projects in 91 of Iowa's 99 counties. Table 1 shows the distribution of projects and funding from the program. Over three-quarters of the projects were placed in towns with fewer than 10,000 residents, and only 13 percent were located in towns with populations over 50,000. Thirty-four percent of the projects and 33 percent of the allocated funds were assigned to cultural amenities (e.g., museums, art centers, libraries). Investments in recreational and outdoor amenities (e.g. aquatic centers, walking/hiking trails, fairground improvements, sports complexes etc.) represented 56 percent of all projects but just 26 percent of all funds, and so recreational amenities tended to be smaller on average. In contrast, entertainment amenities (e.g. theaters, opera houses, accounted for 10 percent of the projects but 42 percent of all funds, so entertainment projects were much larger than average.

The state's cumulative investment in local amenities reached $\$ 75$ per capita by 2008 or about \$2.3 million per county. The local counties' matching expenditures averaged around \$9.6 million for a cumulative average of $\$ 11.9$ million expended on local projects per county. Because projects were implemented in most counties, the average amount spent on projects in neighboring counties per capita swamps the amount in county, averaging $\$ 116$ million in amenities in the surrounding communities. After 2008, the program was sharply diminished in size, funding only a handful of projects thereafter.

Although not by deliberate design, the Vision Iowa project offers an opportunity to examine whether state grants designed to induce new local public amenities actually result in a more efficient provision of public services. Efficiency is enhanced if we can demonstrate positive spillovers from these local projects that go to nonresidents because it suggests that in the absence of state infusion, local communities would have underinvested in the amenity. In the case of the types of tourism-related projects funded by the Vision Iowa program, the most plausible source of a positive spillover is an increase in revenue from taxable retail sales that go

\footnotetext{
${ }^{4}$ Casinos first opened in Iowa as river boats in 1990 and as fixed locations in 1992. Earlier in 1985, the State had allowed the opening of dog racing and in 1989, horse racing. There is no apparent link between Casinos and Vision Iowa beyond serving as a source of revenue.
}

(C) Southern Regional Science Association 2014. 
Table 1: Distribution of Vision Iowa Projects and Funds

\begin{tabular}{|c|c|c|c|c|}
\hline & $\begin{array}{l}\text { Number of } \\
\text { Projects }\end{array}$ & $\%$ of Total & $\begin{array}{l}\text { Amount of } \\
\text { Funds } \\
\text { (in millions) }\end{array}$ & $\%$ of Total \\
\hline Total Projects & 357 & & $\$ 368.41$ & \\
\hline Projects in Casino Counties & 81 & $22.69 \%$ & $\$ 233.24$ & $63.3 \%$ \\
\hline \multicolumn{5}{|c|}{ Number of Projects By Project Type } \\
\hline Cultural & 122 & $34.17 \%$ & $\$ 119.80$ & $32.5 \%$ \\
\hline Recreational/Outdoor & 201 & $56.30 \%$ & $\$ 95.82$ & $26.0 \%$ \\
\hline Entertainment & 34 & $9.52 \%$ & $\$ 152.79$ & $41.5 \%$ \\
\hline \multicolumn{5}{|l|}{ Project in County By Population } \\
\hline Population under 10,000 & 275 & $77.03 \%$ & $\$ 75.98$ & $20.6 \%$ \\
\hline $\begin{array}{l}\text { Population between } 10,000 \text { and } \\
50,000\end{array}$ & 37 & $10.36 \%$ & $\$ 57.14$ & $15.5 \%$ \\
\hline Population over 50,000 & 45 & $12.61 \%$ & $\$ 235.29$ & $63.9 \%$ \\
\hline
\end{tabular}

to jurisdictions other than the local area receiving the new amenity. Clear evidence of a positive spillover exists if increased tourism raises sales not just in the own community, but in neighboring communities as well. In addition, the State of Iowa benefits as it gets five of every seven cent tax imposed per dollar of induced increase in taxable retail sales. However, if the investment in one county lowers taxable retail sales in neighboring communities, then there are negative spillover effects from the Vision Iowa projects. If that is true, the state grants for local provision of public amenities will cause overproduction of public goods which will harm the state as a whole.

\section{EMPIRICAL MODEL}

Let real taxable sales in county $i$ at time $t$ be represented by $S_{i t}$. We assume that in the absence of any policy shocks, real sales are defined by

$$
\ln \left(S_{i t}\right)=\alpha_{0 i}+\alpha_{1 i} t+\alpha_{2 i} t^{2}+\alpha_{M} M_{t}+\varepsilon_{i t}
$$

Each county $i$ has unique fixed attributes that define its base level of sales, $\alpha_{0 i}$. The county's resource bases in land, labor, and capital define its productive capacity, which establishes its base consumption level. Such resources would include natural amenities, access to navigable waters, long-standing public infrastructure such as highway or rail access, and the presence of higher education institutions. We estimate the county-specific fixed effects using only the sales before the Vision Iowa program began to avoid adding in the impact of the built amenities into the fixed effect.

Each county also has a unique trend growth rate of $\alpha_{1 i}$ per year. We allow this trend to grow or diminish over time with a quadratic term in time. Finally, state-wide business cycles indexed by $M_{t}$, raise or lower sales across all counties. These county-specific fixed effects and trends plus the state-wide cyclical variable explain over 98 percent of the variance in the dependent variables we use to measure county output. The error term $\varepsilon_{i t}$ representing less than 2 
percent of the remaining variation contains remaining factors that affect county sales that are uncorrelated with the factors included in (1).

A county's real sales process shifts when exposed to a local public amenity, $A_{i t}$, provided of course that the amenity attracts additional productive resources. These may be additional visitors that create additional demand for local retailers or the amenity may complement existing resources in the county, raising productive efficiency. In the Vision Iowa program, these amenities are funded in part by the state and in part by local taxpayers. The impacts of the two funding sources on taxable sales would not be the same in general because the state subsidy comes without the need for local taxes while the local expenditures require commitment of local resources equal to the value of the amenity. The local tax obligation may lower taxable purchases by local taxpayers.

Even as the home county $i$ is deciding whether to invest in new amenities, neighboring counties may also be introducing man-made amenities, $N_{i t}$. These amenities may increase or decrease sales in the home county. If such amenities substitute for one another, local sales will decrease in the presence of competing amenities elsewhere. If such amenities complement each other, the opposite will occur. These policy shocks are part of the error process in (1). We assume they take the form $\varepsilon_{i t}=\ln \left(A_{i t}^{\gamma_{A}}\right)+\ln \left(N_{i t}^{\gamma_{N}}\right)+\omega_{i t}$. Substituting into (1), we have

$$
\ln \left(S_{i t}\right)=\alpha_{0 i}+\alpha_{1 i} t+\alpha_{2 i} t^{2}+\alpha_{M} M_{t}+\gamma_{A} \ln \left(A_{i t}\right)+\gamma_{N} \ln \left(N_{i t}\right)+\omega_{i t}
$$

The term $\omega_{i t}$ is an i.i.d error process. The sign and significance of $\gamma_{A}$ and $\gamma_{N}$ will reveal whether local and area amenities affect local taxable sales and whether neighboring amenities are substitutes or complements.

To operationalize (2), we need to specify the functional form for $A_{i t}$ and $N_{i t}$. Note that these amenities were introduced first in 2000, and so we set them equal to 1 before 2000 and for each year thereafter until the first Vision Iowa dollar is spent in the county. We specify the quantity of local public amenities per person as

$$
\begin{aligned}
A_{i t} & =V_{i t}^{\beta_{V}} L_{i t}^{\beta_{L}}, \quad t \geq 2000, \text { if } V_{i t}>0 \\
& =1, t \geq 2000, \text { if } V_{i t}=0 \\
& =1, t<2000
\end{aligned}
$$

where $V_{i t}$ is the cumulative infusion of the state's provision of real Vision Iowa funds into the local county since 2000 and $\mathrm{L}_{\mathrm{it}}$ is the cumulative real per capita local expenditures on these projects since 2000. If the production of local amenities uses resources efficiently, then $\beta_{V}>0$ and $\beta_{L}>0$. These dollar amounts are in per capita terms, implying that a dollar of public good will have a smaller sales spillover effect in a metropolitan area than in a small town. The rationale is that cultural, entertainment and recreational amenities face congestion costs and must be scaled up in more populated areas.

We model neighboring amenities similarly as

$$
\begin{aligned}
N_{i t} & =V_{l_{i} t}^{\theta_{V}} L_{l_{i} t}^{\theta_{L}}, \quad t \geq 2000, \text { if } V_{i t}>0 \\
& =1, t \geq 2000, \text { if } V_{i t}=0 \\
& =1, t<2000 .
\end{aligned}
$$

$V_{\text {lit }}$ is the cumulative Vision Iowa investment in all contiguous counties to $i$. The contiguous county's local real per capita cumulative investments in these projects is given by $L_{\text {lit }}$. 
As before, if these investments have positive spillovers, then $\theta_{V}>0$ and $\theta_{L}>0$. However, if they compete with home county sales, they will have negative signs.

Inserting (3) and (4) into Equation (2), we have

$$
\begin{gathered}
\ln \left(S_{i t}\right)=\alpha_{0 i}+\alpha_{1 i} t+\alpha_{2 i} t^{2}+\alpha_{M} M_{t}+\gamma_{A} \beta_{V} \ln \left(V_{i t}\right)+\gamma_{A} \beta_{L} \ln \left(L_{i t}\right)+ \\
\gamma_{N} \theta_{V} \ln \left(V_{l_{i} t}\right)+\gamma_{N} \theta_{L} \ln \left(L_{l_{i} t}\right)+\omega_{i t}
\end{gathered}
$$

the empirical specification we use to test the impact of the Vision Iowa program. Note that the coefficients on the dollars spent on local amenities will be the product of two effects: the productivity of the dollars in generating a quality public amenity and the impact of the amenity on sales. Under the maintained hypothesis that these dollars are used efficiently, the signs on these compound coefficients will still reveal whether the own county and neighboring county amenities raise or lower local sales.

We use several alternative measures of the dependent variable. In addition to taxable retail sales, we also specify taxable sales in sectors that should atypically benefit from increased tourism such as those in eating and drinking establishments. Further, we have information on the total number of firms and on the number of eating and drinking establishments which we use as alternative outcome measures.

\section{CONDITIONAL IMPACT EVALUATION}

Many evaluations attempt to derive unconditional estimates of the impact of a policy using randomized experiments. That type of analysis is inconsistent with a policy such as the Vision Iowa program. A local area will not adopt a randomly selected public project; that would be inconsistent with rational administration of their scarce public dollars. Similarly the State would not randomly assign scarce resources to pay a portion of the costs of these programs. Nonrandom selection of projects and their placement is a key element of the fiscal federalist approach. Consequently, our estimated impacts are conditional on a project being sufficiently promising to induce the locality to allocate money toward it and sufficiently worthwhile to convince a state board to allocate additional funds. Note that there is no guarantee that such projects actually pay off. They might crowd out sales in neighboring localities or just fail to generate sufficient new visitors to pay for themselves.

While our estimate of the project impact is conditional on projects being acceptable to both the locality and the state, it is useful to note that the estimator will be holding constant the same local fixed effects, past trend growth, and state-wide cyclical factors we are using to set the expected county growth in sales. To see this, suppose that the joint decision $V_{j i}$ between the state and locality $i$ to fund a project $j$ is based on their expectations regarding ability to pay. That assessment would take the form:

$$
\begin{gathered}
V_{j i t}=1 \text { if } \varphi_{0 i}+\varphi_{1 i} t+\varphi_{2 i} t^{2}+\varphi_{M} M_{t}>-\xi_{i j t}, \text { indicating project approval, and } \\
V_{j i t}=0 \text { otherwise. }
\end{gathered}
$$

This specification suggests that the approved projects would depend on county-specific fixed effects that would control for the local debt and strength of their existing tax base, trend growth in the local economy that would affect future ability to fund public goods, and the strength of the state economy that would affect the state's interest in co-funding local projects. The specification in (5) includes the projects that passed the bar defined by (6). Consequently, 
the coefficients $\alpha_{0 i}, \alpha_{1 i}, \alpha_{2 i}$, and $\alpha_{M}$ will control for both the expected growth in county sales in the absence of the new public amenities as well as the impact of these same factors on the likelihood that an amenity is funded. Any remaining impact of the local or neighboring community projects on county taxable sales will reflect the impact of the unobserved project quality $\xi_{i t}$ on sales. Therefore our conditional estimate of the impact of the Vision Iowa projects will be purged of the influence of past county fiscal strength, past trend growth in sales and tax revenue, and state macroeconomic shocks.

Our results generalize to similar projects that involve the most promising tourism projects that would pass both local and state funding reviews. Only the most promising projects will ever be undertaken. Our estimates will overstate returns to randomly placed and/or designed public amenities that do not require local funding or pass a state review, but such projects will never be observed in the real world.

\section{DATA}

We assume that the local authority is the county and that the indicator of amenity success or failure will depend on retail sales or the number of firms servicing the retail sector. In Iowa, data on retail sales, $S_{i t}$, and number of firms by county are available from the Iowa Retail Sales and Use Tax Reports, published annually by the Iowa Department of Revenue and Finance beginning in 1976. Sales of all taxable goods and services and number of firms are reported in total and by two digit merchandise categories as long as five or more businesses within the category report data. Overall taxable retail sales are available for every county and year, and data for eating and drinking establishments is available for all but four possible county-year cells. This provides us a comprehensive 32-year window for each county to evaluate whether the program has any impact on consumer purchases. Summary statistics are reported in the appendix.

The Iowa Department of Economic Development compiled data on every Vision Iowa project including local and state contributions, location, and project type and date. All necessary information on cumulative investments in Vision Iowa projects by county was culled from those online reports. We convert the nominal sales data reported by the state to real (2008) dollars using the all item urban consumer price index (CPI-U) from the Bureau of Labor Statistics. The resulting state $\left(V_{i t}\right)$ and local $\left(L_{i t}\right)$ cumulative expenditures on local amenities were converted to per capita terms using the county population in 2000. Our analogously computed measure of cumulative per capita amenity expenditures in neighboring counties is based on all counties with a common border excluding counties that only touch at the corners.

Our control variables include 99 county fixed effects and 99 county-specific trend terms. We also include a squared trend term that we constrain to have a common effect across the 28 smallest counties with less than 12,000 population; a common effect across the 56 intermediate counties with populations between 12 and 50 thousand; and a third common effect on the squared trend of the remaining 15 metro counties. ${ }^{5}$ Our control for the strength of the state economy is the annual state unemployment rate reported by the Bureau of Labor Statistics. Finally, research has shown that economic growth is correlated across counties roughly within

\footnotetext{
${ }^{5}$ Our specification of the quadratic term was based on a preliminary analysis of sales trends by county size. We found that in the years preceding the installation of the Vision Iowa program, the log of real taxable sales declined at an increasing rate in the smallest counties and rose at an increasing rate in the largest counties.
}

(C) Southern Regional Science Association 2014. 
commuting distance of one another (Wheeler 2001; Khan, Orazem, and Otto 2001). To account for this, we allow for spatial error dependence by estimating clustered standard errors which assume correlation among counties in the same economic region, but no correlation across regions. In addition, we estimate a double clustering model to also control for idiosyncratic and persistent time specific effects (Thompson 2011).

\section{RESULTS}

Table 2 reports the results of our estimation of Equation (5) using the natural log of real taxable retail sales and of real taxable sales in eating and drinking establishments as the dependent variable. The specification includes 99 county-specific constants, $\alpha_{0 i}$, 99 countyspecific linear trends $\alpha_{1 i}$, and 3 quadratic trend terms for small, intermediate, and large counties. These 201 coefficients are estimated but not reported. The first column is the reduced form effect of the state Vision Iowa subsidy on the own county and any potential spillover effects from grants awarded to neighboring counties. The focus on only the state subsidy in the own and neighboring counties effectively constrains the local expenditure effects $\beta_{L}=\theta_{L}=0$. Because the Vision Iowa subsidy requires local effort, the second column separates the Vision Iowa effect into the direct effect of the subsidy plus any indirect effect from induced local expenditures. This specification includes the full set of four parameters reflecting responses to cumulative per capita state and local expenditures on Vision Iowa projects in the own and neighboring counties. The reduced form effects in the first column can be compared to the corresponding summed effects of the subsidy and the induced local expenditure in the second column.

Turning to the first column, we find that a one percent increase in per capita cumulative state Vision Iowa subsidy to the county results in a 0.01 percent increase in county taxable retail sales. The effect is quite large: a one percent increase in per capita subsidy amounts to about $\$ 15,000$ spent on the local amenity, but the induced increase in taxable sales is nearly $\$ 32,000$ per year. The literal implication of this result is that local built amenities are complements with local purchases in the retail and hospitality sectors. The state's share in the form of a five percent sales tax on induced increases in sales is $\$ 1,600$ per year, implying a state return of 10.7 percent per year per $\$ 15,000$ invested.

The state subsidy in any one county does not occur in a vacuum as the state is investing in other counties as well. Investments in neighboring counties may compete with the effectiveness of the state subsidy in the own county. However, it appears that Vision Iowa investments are complementary across counties. Local county sales increase 0.003 percent from every one percent increase in per capita subsidies in the neighboring counties. As a result, even counties that did not receive a subsidy benefited from state investments in their neighbors. These implied effects are modest, adding $\$ 9,630$ in local taxable sales from a one percent increase in public amenities located in surrounding communities. Nevertheless, the key finding is that investments in one town do not reduce economic activity in the surrounding towns.

The reason the state gets such a large return on its investment is that it is only investing a fraction of the cost of the local project, but with its 5 percent state sales tax, it gets a disproportionate share of any induced return. In contrast, the local constituents provide over 80 percent of the cost of the project on average but can only charge a maximum sales tax of two percent on the induced increase in sales.

(C) Southern Regional Science Association 2014. 


\section{Table 2: Regressions of the Log of Real County Taxable Sales on Cumulative Vision Iowa Expenditures per Capita}

\begin{tabular}{|c|c|c|c|c|}
\hline Own County & \multicolumn{2}{|c|}{ Total Sales } & \multicolumn{2}{|c|}{$\begin{array}{l}\text { Eating and Drinking } \\
\text { Establishment Sales }\end{array}$} \\
\hline $\ln \left(V_{i t}\right)$ & $\begin{array}{c}0.010 * * * \\
(3.82)\end{array}$ & $\begin{array}{c}0.005 \\
(1.60)\end{array}$ & $\begin{array}{c}0.008 * * * \\
(3.23)\end{array}$ & $\begin{array}{l}0.005 \\
(1.39)\end{array}$ \\
\hline $\ln \left(L_{i t}\right)$ & ---- & $\begin{array}{l}0.005 \\
(1.11)\end{array}$ & ---- & $\begin{array}{l}0.003 \\
(0.71)\end{array}$ \\
\hline \multicolumn{5}{|l|}{ Surrounding Counties } \\
\hline $\ln \left(V_{l_{i} t}\right)$ & $\begin{array}{l}0.003 \\
(1.30)\end{array}$ & $\begin{array}{l}-0.004 \\
(0.318)\end{array}$ & $\begin{array}{c}-0.004 * * \\
(2.25)\end{array}$ & $\begin{array}{l}0.013 \\
(0.71)\end{array}$ \\
\hline $\ln \left(L_{l_{i} t}\right)$ & ---- & $\begin{array}{l}0.007 \\
(0.34)\end{array}$ & ---- & $\begin{array}{l}-0.015 \\
(0.89)\end{array}$ \\
\hline$M_{t}$ & $\begin{array}{c}-0.027 * * * \\
(4.63)\end{array}$ & $\begin{array}{c}-0.027 * * * \\
(4.63)\end{array}$ & $\begin{array}{c}-0.016 * * * \\
(4.63)\end{array}$ & $\begin{array}{c}-0.016 * * * \\
\quad(4.62)\end{array}$ \\
\hline $\mathrm{N}$ & 3267 & 3267 & 3266 & 3266 \\
\hline $\mathrm{R}^{2}$ & 0.99 & 0.99 & 0.99 & 0.99 \\
\hline Marginal $\mathrm{R}^{2}$ & & 0.06 & & 0.03 \\
\hline $\begin{array}{l}\text { Summed Effects } \\
\ln \left(V_{i t}\right)+\ln \left(L_{i t}\right)\end{array}$ & & $\begin{array}{l}0.010 * * * \\
(4.10)\end{array}$ & & $\begin{array}{c}0.008 * * * \\
\quad(3.31)\end{array}$ \\
\hline $\ln \left(V_{l_{i} t}\right)+\ln \left(L_{l_{i} t}\right)$ & & $\begin{array}{l}0.003 \\
(0.76)\end{array}$ & & $\begin{array}{l}-0.003 \\
(1.38)\end{array}$ \\
\hline $\ln \left(V_{i t}\right)+\ln \left(L_{i t}\right)+\ln \left(V_{l_{i} t}\right)$ & $+\ln \left(L_{l_{i} t}\right)$ & $\begin{array}{l}0.013 * * * \\
(4.59)\end{array}$ & & $\begin{array}{c}0.005 * * \\
(2.47)\end{array}$ \\
\hline County Fixed Effects & $\sqrt{1}$ & $\sqrt{ }$ & $\sqrt{1}$ & $\sqrt{ }$ \\
\hline County-specific trends & $\sqrt{ }$ & $\sqrt{ }$ & $\sqrt{ }$ & $\sqrt{ }$ \\
\hline County group squared trend & $\sqrt{ }$ & $\sqrt{ }$ & $\sqrt{ }$ & $\sqrt{ }$ \\
\hline
\end{tabular}

Note: Cluster-consistent $t$-statistics in parentheses. Asterisks denote significance: $*$ significant at the 10-percent level; ** significant at the 5-percent level; *** significant at the 1-percent level. The $R^{2}$ is artificially inflated by the fact that the county-specific trends and dummy variables alone can explain 98 percent of the variance in log real taxable sales across counties and time. The marginal $R^{2}$ is the fraction of the variance of the demeaned and detrended dependent variable that can be explained by the model. 
By including the local expenditure measures $\ln \left(L_{i t}\right)$ and $\ln \left(L_{l i t}\right)$ as additional regressors, we can decompose the reduced form effect of the state subsidy into components attributed to the share of the project costs borne by the local entity and the share borne by the state. The results are reported in the second column. Turning first to the own county effects, the returns to a one percent increase in the per capita state subsidy ( 0.005 percent) is virtually identical to the return to a one percent increase in per capita local expenditure. This is true despite the fact that a one percent increase in local expenditures implies a dollar amount more than four times larger than the one percent increase in Vision Iowa subsidy. The key difference is that the local expenditure requires that the community raise property taxes to pay for the project. Presumably, the implied decline in local after-tax income would reduce sales, even as the project might induce increased sales. In contrast, the state subsidy is paid by Casino earnings which have no attached local tax obligation.

When we include both $\ln \left(V_{i t}\right)$ and $\ln \left(L_{i t}\right)$, neither coefficient is statistically significant. Because the amount of the local match is tied to the amount of the state award, $\ln \left(V_{i t}\right)$ and $\ln \left(L_{i t}\right)$ are highly correlated, ${ }^{6}$ our difficulty in estimating their independent effects is not surprising. Nevertheless, the summed effect of 0.01 , interpretable as the elasticity from a one percent increase in both local expenditure and state subsidy, is highly significant and virtually identical to the reduced form effect of $\ln \left(V_{i t}\right)$ in the first column.

The summed elasticity of local taxable sales to a one percent increase in state and local Vision Iowa expenditures in surrounding counties is 0.003 , virtually identical to the estimate in column one. While the individual coefficients are not precisely estimated, their relative magnitudes are sensible. For the spill-in benefits, it is presumably the size of the project that matters most and not the funding source as the own county would incur no tax liabilities to fund projects in neighboring counties.

Overall, the combined effect of a one percent expansion of Vision Iowa funding across the 99 counties, an investment of just under $\$ 1.5$ million in local amenities, raised real taxable sales by 0.013 percent. To put that effect in perspective, a one point increase in the unemployment rate lowers taxable sales by roughly twice that level.

The summed elasticity of local taxable sales to a one percent increase in state and local Vision Iowa expenditures in surrounding counties is 0.003 , virtually identical to the estimate in column one. While the individual coefficients are not precisely estimated, their relative magnitudes are sensible. For the spill-in benefits, it is presumably the size of the project that matters most and not the funding source as the own county would incur no tax liabilities to fund projects in neighboring counties.

Overall, the combined effect of a one percent expansion of Vision Iowa funding across the 99 counties, an investment of just under $\$ 1.5$ million in local amenities, raised real taxable sales by 0.013 percent. To put that effect in perspective, a one point increase in the unemployment rate lowers taxable sales by roughly twice that level.

The last two columns replicate the exercise except that we focus exclusively on taxable sales from eating and drinking establishments. Here we find that projects in surrounding counties compete with own county projects in attracting customers. Apparently restaurant and bar sales

\footnotetext{
${ }^{6}$ The correlation coefficient between the state contribution $\ln \left(V_{i t}\right)$ and the local match $\ln \left(L_{i t}\right)$ is 0.986 . The correlation between these measures in neighboring counties is 0.99 .
}

(C) Southern Regional Science Association 2014. 
are more closely tied to proximity of cultural, recreational, and entertainment amenities than are retail sales in general. Nevertheless, the overall effect on taxable eating and drinking establishment sales of a one percent increase in state and local per capita Vision Iowa expenditures in own and neighboring counties is 0.004 percent, about one-third of the magnitude for retail sales as a whole.

The results in Table 2 show significant evidence of spillover benefits from a local built amenity to neighboring counties in the form of increased sales and to the state in the form of increased sales taxes. As we only observe completed projects, we cannot test whether the state subsidy increases local effort to build public amenities. However, the existence of these external benefits to other jurisdictions as well as to the state implies that the localities would have invested less than the optimum amount on local amenities in the absence of the Vision Iowa program.

Table 3 shows the corresponding effects of Vision Iowa subsidies and community expenditures on the number of firms per capita in the county or in eating and drinking establishments. The specification is the same as in Table 1. In the first column, we find no significant effect of the Vision Iowa funds spent locally, but a negative effect of Vision Iowa funds spent in surrounding counties. While the estimate for neighboring counties is statistically significant, it is not large. This is sensible as the induced increase in taxable sales would not be sufficiently large to accommodate even one more firm. A one percent increase in the subsidy in the surrounding counties would lower the number of local firms by less than one firm. Thus, while the coefficients are significant, the economic importance of the effect is negligible.

The balance of the results in Table 3 does not change the story. Local investments in public amenities have a significant but very small impact on the number of local firms while investments in surrounding communities have small negative effects on the number of local firms. The summed effect of Vision Iowa investments in the local and surrounding communities would have a net negative effect that implies less than one lost firm per one percent increase in investment. Consequently, this program had negligible effects on firm entry and exit. The increase in sales we found from Vision Iowa investments in Table 1 came virtually entirely from expanding sales in preexisting firms.

An additional issue is whether local amenities have larger effects in larger cities relative to small towns. Our measure of amenity investment is in per capita terms, but if there are scale effects we would find larger impacts in urban than rural areas. We include a term that interacts the Vision Iowa infusion in the own and neighboring counties $\left(\ln \left(V_{i t}\right)\right.$ and $\left.\ln \left(V_{l t}\right)\right)$ with an urban dummy variable. These results are presented in Table 4 . The own county impact of Vision Iowa investments are not significantly different for rural and urban counties; however, the spillovers are different. Investments made in urban counties have relatively large, positive spillovers to neighboring counties' retail sales and no impact on the neighboring number of firms. The benefits of amenity investments in rural counties come in part by poaching sales and firms from their neighbors.

To illustrate the magnitude of these effects, we report the implied impact of a one dollar per capita infusion in Vision Iowa subsidy or local expenditure match in the local county or in the surrounding counties. A one dollar per capita increase corresponds to a $\$ 29,014$ in aggregate expenditure when we apply the average county population over the sample period. These results, 
Table 3: Regressions of the Log of Firm Numbers on Cumulative Vision Expenditures per Capita

\begin{tabular}{|c|c|c|c|c|}
\hline & \multicolumn{2}{|c|}{ Total Firms } & \multicolumn{2}{|c|}{$\begin{array}{c}\text { Eating and Drinking } \\
\text { Establishments }\end{array}$} \\
\hline $\ln \left(V_{i t}\right)$ & $\begin{array}{l}0.001 \\
(0.51)\end{array}$ & $\begin{array}{l}-0.002 \\
(0.92)\end{array}$ & $\begin{array}{c}0.006 * * * \\
(3.39)\end{array}$ & $\begin{array}{l}-0.004 \\
(-1.38)\end{array}$ \\
\hline $\ln \left(L_{i t}\right)$ & ---- & $\begin{array}{c}0.003 * * \\
(2.03)\end{array}$ & ---- & $\begin{array}{l}0.009 * * * \\
(3.34)\end{array}$ \\
\hline \multicolumn{5}{|l|}{ Surrounding Counties } \\
\hline $\ln \left(V_{l_{i} t}\right)$ & $\begin{array}{c}-0.009 * * * \\
(3.82)\end{array}$ & $\begin{array}{l}0.008 \\
(0.63)\end{array}$ & $\begin{array}{l}-0.010 * * * \\
(5.64)\end{array}$ & $\begin{array}{l}-0.010 \\
(0.68)\end{array}$ \\
\hline $\ln \left(L_{l_{i} t}\right)$ & ---- & $\begin{array}{l}-0.015 \\
(1.32)\end{array}$ & ---- & $\begin{array}{l}-0.003 \\
(0.02)\end{array}$ \\
\hline$M_{t}$ & $\begin{array}{l}0.009 * * * \\
(2.93)\end{array}$ & $\begin{array}{l}0.010 * * * \\
(2.93)\end{array}$ & $\begin{array}{l}0.014 * * * \\
(5.14)\end{array}$ & $\begin{array}{l}0.014 * * * \\
(5.15)\end{array}$ \\
\hline$N$ & 3267 & 3267 & 3263 & 3263 \\
\hline $\begin{array}{l}R^{2} \\
\text { Marginal } R^{2}\end{array}$ & 0.99 & $\begin{array}{l}0.99 \\
0.07\end{array}$ & 0.98 & $\begin{array}{l}0.98 \\
0.04\end{array}$ \\
\hline \multicolumn{5}{|l|}{ Summed Effects } \\
\hline $\ln \left(V_{i t}\right)+\ln \left(L_{i t}\right)$ & & $\begin{array}{l}0.001 \\
(0.51)\end{array}$ & & $\begin{array}{l}0.005 * * * \\
(2.91)\end{array}$ \\
\hline $\ln \left(V_{l_{i} t}\right)+\ln \left(L_{l_{i} t}\right)$ & & $\begin{array}{c}-0.008 * * * \\
(3.42)\end{array}$ & & $\begin{array}{c}-0.010 * * * \\
\quad(4.25)\end{array}$ \\
\hline $\ln \left(V_{i t}\right)+\ln \left(L_{i t}\right)+\ln \left(V_{l_{i} t}\right.$ & $\mathrm{a}\left(L_{l_{i} t}\right)$ & $\begin{array}{l}-0.007 * * * \\
\quad(5.18)\end{array}$ & & $\begin{array}{l}-0.005 * * * \\
\quad(3.31)\end{array}$ \\
\hline County Fixed Effects & $\sqrt{ }$ & $\sqrt{ }$ & $\sqrt{ }$ & $\sqrt{ }$ \\
\hline County-specific linear trend & $\sqrt{ }$ & $\sqrt{ }$ & $\sqrt{ }$ & $\sqrt{ }$ \\
\hline County group squared trend & $\sqrt{ }$ & $\sqrt{ }$ & $\sqrt{ }$ & $\sqrt{ }$ \\
\hline
\end{tabular}

Note: Cluster-consistent t-statistics in parentheses. * significant at the 10-percent level; ** significant at the 5-percent level; *** significant at the 1-percent level. The R2 is artificially inflated by the fact that the county-specific trends and dummy variables alone can explain 98 percent of the variance in $\log$ real taxable sales across counties and time. The marginal R2 is the fraction of the variance of the demeaned and detrended dependent variable that can be explained by the model.

(C) Southern Regional Science Association 2014. 
Table 4: Regressions of the Log of Real County Taxable Sales on Cumulative Vision Iowa Expenditures per Capita for Rural and Urban Counties

\begin{tabular}{|c|c|c|c|c|}
\hline & Total Sales & $\begin{array}{c}\text { Eating and } \\
\text { Drinking } \\
\text { Establishment } \\
\text { Sales } \\
\end{array}$ & Total Firms & $\begin{array}{c}\text { Eating and } \\
\text { Drinking } \\
\text { Firms } \\
\end{array}$ \\
\hline \multicolumn{5}{|l|}{ Own County } \\
\hline $\ln \left(V_{i t}\right)$ & $\begin{array}{l}0.007 * * * \\
\quad(6.01)\end{array}$ & $\begin{array}{l}0.005 * * * \\
(2.83)\end{array}$ & $\begin{array}{l}-0.001 \\
(0.38)\end{array}$ & $\begin{array}{l}0.004 * * * \\
(2.64)\end{array}$ \\
\hline $\ln \left(V_{i t}\right) x$ urban & $\begin{array}{l}-0.004 \\
(0.79)\end{array}$ & $\begin{array}{r}-0.003 \\
(0.63)\end{array}$ & $\begin{array}{l}0.000 \\
(0.20)\end{array}$ & $\begin{array}{r}-0.002 \\
(0.47)\end{array}$ \\
\hline \multicolumn{5}{|l|}{ Surrounding Counties } \\
\hline $\ln \left(V_{l_{i} t}\right)$ & $\begin{array}{l}0.002 \\
(1.23)\end{array}$ & $\begin{array}{l}-0.005 * * * \\
(4.23)\end{array}$ & $\begin{array}{c}-0.010 * * \\
(10.45)\end{array}$ & $\begin{array}{l}-0.011 * * * \\
(9.23)\end{array}$ \\
\hline $\ln \left(V_{l_{i} t}\right) \times$ urban & $\begin{array}{l}0.026 * * * \\
(4.01)\end{array}$ & $\begin{array}{l}0.021 * * * \\
(3.52)\end{array}$ & $\begin{array}{c}0.009 * * \\
(3.54)\end{array}$ & $\begin{array}{l}0.013 * * * \\
(4.33)\end{array}$ \\
\hline $\begin{array}{l}N \\
R^{2}\end{array}$ & $\begin{array}{l}3267 \\
0.56\end{array}$ & $\begin{array}{c}3266 \\
0.31\end{array}$ & $\begin{array}{l}3267 \\
0.49\end{array}$ & $\begin{array}{l}3263 \\
0.27\end{array}$ \\
\hline $\begin{array}{l}\text { Summed Effects } \\
\ln \left(V_{i t}\right)+\ln \left(V_{i t}\right) x \text { urban }\end{array}$ & $\begin{array}{l}0.003 \\
(0.55)\end{array}$ & $\begin{array}{l}0.003 \\
(0.76)\end{array}$ & $\begin{array}{l}0.000 \\
(0.03)\end{array}$ & $\begin{array}{l}0.002 \\
(0.88)\end{array}$ \\
\hline $\ln \left(V_{l_{i} t}\right)+\ln \left(V_{l_{i} t}\right) \times$ urban & $\begin{array}{c}0.028 * * * \\
(4.20) \\
\end{array}$ & $\begin{array}{l}0.016 * * * \\
(2.66)\end{array}$ & $\begin{array}{r}-0.001 \\
(0.24) \\
\end{array}$ & $\begin{array}{l}0.003 \\
(0.90) \\
\end{array}$ \\
\hline County Fixed Effects & $\sqrt{ }$ & $\sqrt{ }$ & $\sqrt{ }$ & $\sqrt{ }$ \\
\hline County-specific trends & $\sqrt{ }$ & $\sqrt{ }$ & $\sqrt{ }$ & $\sqrt{ }$ \\
\hline County group squared trend & $\sqrt{ }$ & $\sqrt{ }$ & $\sqrt{ }$ & $\sqrt{ }$ \\
\hline
\end{tabular}

Note: Cluster-consistent $t$-statistics in parentheses. Asterisks denote significance: $*$ significant at the 10-percent level; ** significant at the 5-percent level; *** significant at the 1-percent level.

based on simulations of the second and fourth columns of Tables 2 and 3, are reported in Table 5.

First, looking at the effects on total sales, we can see that a one dollar per capita infusion of Vision Iowa grant results in an annual increase of total taxable sales of $\$ 37,246$. This is not the full effect as the infusion requires a local match. The effect of one dollar per capita of Vision Iowa subsidy plus a one-dollar per capita local match rises to $\$ 45,044$ in increased sales per year. Similar investments are occurring in other counties that could complement or compete with local sales. When we add an additional dollar per capita in Vision Iowa subsidy and a one-dollar local match in the surrounding counties, we find that local sales rise by $\$ 43,896$. 
Table 5: Implied Real Returns from a One Dollar per Capita Vision Iowa Subsidy or Expenditure ${ }^{\text {a }}$

\begin{tabular}{lclc}
\hline \hline $\begin{array}{l}\text { Dollar Change per } \\
\text { Capita }\end{array}$ & $\begin{array}{c}\text { Change in } \ldots . . \\
\text { Total Sales }\end{array}$ & $\begin{array}{l}\text { Dollar Change per } \\
\text { Capita }\end{array}$ & $\begin{array}{l}\text { Change in .... } \\
\text { Eating and } \\
\text { Drinking Sales }\end{array}$ \\
\hline \hline$V_{i t}$ & $\$ 37,246$ & $V_{i t}$ & $\$ 2,964$ \\
$L_{i t}$ & $\$ 7,798$ & $L_{i t}$ & $\$ 479$ \\
$V_{l_{i} t}$ & $-\$ 2,161$ & $V_{l_{i} t}$ & $\$ 580$ \\
$L_{l_{i} t}$ & $\$ 1,012$ & $L_{l_{i} t}$ & $-\$ 195$ \\
$V_{i t}+L_{i t}$ & $\$ 45,044$ & $V_{i t}+L_{i t}$ & $\$ 3443$ \\
$V_{l_{i} t}+L_{l_{i} t}+L_{l_{i} t}$ & $-\$ 1,148$ & $V_{l_{i} t}+L_{l_{i} t}$ & $\$ 385$ \\
$V_{i t}+L_{i t}+V_{l_{i} t}$ & $\$ 43,896$ & $V_{i t}+L_{i t}+V_{l_{i} t}+L_{l_{i} t}$ & $\$ 3,827$ \\
& & & \\
Dollar Change per & & Dollar Change per & Eating and \\
Capita & Total Firms & Capita & Drinking Firms \\
\hline$V_{i t}$ & -0.038 & $V_{i t}$ & -0.007 \\
$L_{i t}$ & 0.014 & $L_{i t}$ & -0.004 \\
$V_{l_{i} t}$ & 0.011 & $V_{l_{i} t}$ & 0.001 \\
$L_{l_{i} t}$ & -0.006 & $L_{l_{i} t}$ & 0.000 \\
$V_{i t}+L_{i t}$ & -0.024 & $V_{i t}+L_{i t}$ & -0.011 \\
$V_{l_{i} t}+L_{l_{i} t}$ & 0.005 & $V_{l_{i} t}+L_{l_{i} t}$ & -0.001 \\
$V_{i t}+L_{i t}+V_{l_{i} t}+L_{l_{i} t}$ & ${ }^{\mathrm{a}} \mathrm{A}$ one-dollar increase per capita corresponds to a $\$ 29,014$ expenditure on average. & -0.010 \\
\hline \hline
\end{tabular}

Is this a good deal for the state? The best measure of the state's return is $V_{i t}+4 * L_{i t}$ from an infusion of one dollar of state Vision Iowa subsidy per capita. The rationale is that each one dollar of state investment generated an average of four dollars of local investment. From the state's perspective, the infusion of $\$ 29,014$ yields an increase in annual taxable sales of $\$ 37,246$ $+4 * \$ 7,798=\$ 68,438$ per year. The state sales tax is five percent of this, or $\$ 3,422$ per year. The internal rate of return for the state is 0.118 . The general equilibrium effects make this a lowerbound estimate of the return, as the Vision Iowa subsidy in one county increases sales modestly in surrounding counties as well. In comparison, the ten-year rate of return on the state's pension program from 2002 to 2012 was 0.0733 .

First, looking at the effects on total sales, we can see that a one dollar per capita infusion of Vision Iowa grant results in an annual increase of total taxable sales of $\$ 37,246$. This is not the full effect as the infusion requires a local match. The effect of one dollar per capita of Vision Iowa subsidy plus a one-dollar per capita local match rises to $\$ 45,044$ in increased sales per year. Similar investments are occurring in other counties that could complement or compete with local sales. When we add an additional dollar per capita in Vision Iowa subsidy and a one-dollar local match in the surrounding counties, we find that local sales rise by $\$ 43,896$.

Is this a good deal for the state? The best measure of the state's return is $V_{i t}+4 * L_{i t}$ from an infusion of one dollar of state Vision Iowa subsidy per capita. The rationale is that each one dollar of state investment generated an average of four dollars of local investment. From the state's perspective, the infusion of $\$ 29,014$ yields an increase in annual taxable sales of $\$ 37,246$ 
$+4 * \$ 7,798=\$ 68,438$ per year. ${ }^{7}$ The state sales tax is five percent of this, or $\$ 3,422$ per year. The internal rate of return for the state is 0.118 . The general equilibrium effects make this a lower-bound estimate of the return, as the Vision Iowa subsidy in one county increases sales modestly in surrounding counties as well. In comparison, the ten-year rate of return on the state's pension program from 2002 to 2012 was 0.0733 .

Is this a good deal for the locality? The local cost is $\$ 116,056$ to generate the annual increase in local sales of $\$ 68,438$. The local sales tax is two percent, so the induced local sales tax revenue is $\$ 1,369$ per year. The internal rate of return is 0.012 or roughly one-tenth the return that goes to the state. However, the local area also gets the value of consuming the new local amenity, and so the true local return must be larger than 0.012 .

It is apparent that the state has a substantial interest in encouraging the development of these local cultural, recreational and entertainment amenities. Just through the induced sales tax revenue, the state makes back a good return on its investment. The return to the local community is much more modest. Because some of the return is externalized and because the local government's return is quite modest even with the subsidy, it seems apparent that the local communities would undersupply these amenities without the state subsidy.

For completeness, we include the related impacts on total firm numbers and on the eating and drinking sector from one dollar per capita investments by source and location. Note that if we continue to apply the four to one average local match required by the program, the implied total effect of a one dollar per capita Vision Iowa infusion on total firm numbers is $-0.038+$ $4^{*} 0.014=0.02$ local firms added to the local market. On net, the Vision Iowa project as implemented has a small positive effect on firm numbers. The general equilibrium effects on other counties go in the opposite direction, so even this modest change in firm numbers is an overestimate.

The impacts on eating and drinking establishments show that the benefits of the program are more broadly felt than just the food service sector. The total sales effect is a factor of ten larger than that on restaurants and bars. As with overall firm numbers, there is only a negligible effect on the number of eating and drinking establishments.

\section{CONCLUSIONS}

For eight years, the State of Iowa offered local areas the possibility of getting a subsidy for approved local built amenities. The Vision Iowa program resulted in 393 new publicly funded local amenities aimed at attracting visitors to the locales. Our analysis indicates that on average, the amenities increased county taxable retail sales relative to the county's past trend sales growth by 0.01 percent for every one percent growth in expenditures on local amenities. These built amenities also had spillover benefits to neighboring communities in the form of smaller induced growth in taxable sales. In addition, because the state taxes each dollar of added sales by five percent, the state receives benefits from the program as well. Viewed as an investment, the State's expenditures on the Vision Iowa program generated an average return of 11.8 percent per year in increased sales tax revenues. The return to the local government's investment was smaller, both because the local sales tax was limited to two percent of taxable sales and because the local share of expenses averaged four times the state share. Nevertheless,

\footnotetext{
${ }^{7}$ This is an underestimate because neighboring counties would have modest increases in taxable sales also.
}

(C) Southern Regional Science Association 2014. 
the local government still garnered a positive tax return at 1.2 percent per year per dollar invested along with the hedonic benefits from the local public good.

Our finding of large conditional returns to local public amenity projects suggests that there may be a value to the selection process itself, above and beyond the allocation of funds for local projects. A commonly prescribed solution for local under-provision of public goods is to institute revenue sharing or block grants whereby the state issues funds to each locality in proportion to its population. However, there is no reason to believe that an equal distribution of funds per capita will be allocatively efficient: equalizing marginal benefit per dollar expended. Our results suggest that in the context of local amenities aimed at tourism, it may be more advisable to make central allocations conditional on the apparent viability of the project proposal. In that way, only the best projects with the largest apparent spillover benefits get funded. As an example, public research funds are commonly allocated by competitive grants going to the best researchers or the most credible proposals rather than by equal distributions allocated to the entire population of potential researchers. In the case of cultural, recreational or entertainment projects aimed at attracting visitors, the joint selection of the most promising projects by the locality and the state may be a critical element of the program's success.

As for the concept of fiscal federalism, our results show why, left to themselves, local areas will underinvest in public amenities aimed at attracting tourists. Because benefits spill over to other communities and to the state as a whole, the subsidy from the state is necessary to induce local communities to provide the efficient level of the local public good. Hence, built local amenities aimed at attracting visitors are a case where fiscal federalism improves local provision of public goods.

\section{People will come, Ray. They'll come to Iowa for reasons they can't even fathom.}

—Terrance Mann to Ray Kinsella, Field of Dreams (1989)

In the case of Vision Iowa projects, they did come, as Karin Kinsella and Terrance Mann predicted. But they only come if the amenity is built. The spillover benefits to other jurisdictions mean that local tourist amenities may, without the state subsidy, remain just a vision or a dream.

\section{REFERENCES}

Agha, Nola. (2013) "The Economic Impact of Stadiums and Teams: The Case of Minor League Baseball," Journal of Sports Economics, 14, 227-252.

Bewley, Truman. (1981) “A Critique of Tiebout's Theory of Local Public Expenditures," Econometrica, 49, 713-740.

Boarnet, Marlon. (1998) "Spillovers and the Locational Effects of Public Infrastructure," Journal of Regional Science, 38, 381-400.

Clark, Terry N. (2003) "Urban Amenities: Lakes, Opera and Juice Bars Do They Drive Development?," in Terry N. Clark, ed., The City as an Entertainment Machine: Research in Urban Policy (Volume 9). JAI Press: New York, 103-140.

Cohen, Jeffrey P. and Catherine Morrison Paul. (2007) "The Impacts of Transportation Infrastructure on Property Values: A Higher-order Spatial Econometrics Approach," Journal of Regional Science, 47, 457-478.

(C) Southern Regional Science Association 2014. 
Deller, Steven C., Tsung-Hsiu Tsai, David W. Marcouiller, and Donald B. K. English. (2001) "The Role of Amenities and Quality of Life in Rural Economic Growth," American Journal of Agricultural Economics, 83, 352-365.

Florida, Richard. (2002) The Rise of the Creative Class. Basic Books: New York.

Glaeser, Edward L. (1996) "The Incentive Effects of Property Taxes on Local Governments," Public Choice, 89, 93-111.

Gordon, Roger H. (1983) "An Optimal Taxation Approach to Fiscal Federalism," The Quarterly Journal of Economics, 98, 567-586.

Hamilton, Bruce W. (1975) "Zoning and Property Taxation in a System of Local Governments," Urban Studies, 12, 205-211.

. (1976) "Capitalization of Intrajurisdictional Differences in Local Tax Prices," American Economic Review, 66, 743-753.

Holl, Adelheid. (2004) "Manufacturing Location and Impacts of Road Transport Infrastructure: Empirical Evidence from Spain," Regional Science and Urban Economics, 34, 341-363.

Khan, Romana, Peter Orazem, and Daniel Otto. (2001) "Deriving Empirical Definitions of Spatial Labor Markets: The Roles of Competing versus Complementary Growth," Journal of Regional Science, 41, 735-756.

Lentz, Bernard F. and David N. Laband. (2009) "The Impact of Intercollegiate Athletics on Employment in the Restaurant and Accommodations Industries," Journal of Sports Economics, 10, 351-368.

McGranahan, David A. (1999) "Natural Amenities Drive Rural Population Change," Report AER 781, Economic Research Service, United States Department of Agriculture: Washington, D.C.

Nelson, Arthur C. (2001) "Prosperity or Blight? A Question of Major League Stadia Locations," Economic Development Quarterly, 15, 255-265.

Nord, Mark and John B. Cromartie. (1997) "Migration: The Increasing Importance of Rural Natural Amenities," Choices, 31-32.

Oates, Wallace E. (1999) “An Essay on Fiscal Federalism,” Journal of Economic Literature, 37, $1120-1149$.

. (2005) "Toward A Second-generation Theory of Fiscal Federalism," International Tax and Public Finance, 12, 349-373.

Olfert, M. Rose and Mark D. Partridge. (2010) "Best Practices in Twenty-first Century Rural Development and Policy," Growth and Change, 41, 147-164.

. (2008) "The Geographic Diversity of U.S. Nonmetropolitan Growth Dynamics: A Geographically Weighted Regression Approach," Land Economics, 84, 214-266.

Pereira, Alfredo Marvão and Oriol Roca-Sagalés. (2003) "Spillover Effects of Public Capital Formation: Evidence from the Spanish Regions," Journal of Urban Economics, 53, 238256.

(C) Southern Regional Science Association 2014. 
Pinto, Santiago M. (2007) "Tax Competition in the Presence of Interjurisdictional Externalities: The Case of Crime Prevention," Journal of Regional Science, 47, 897-913.

Power, Thomas M. (2006) "The Supply and Demand for Natural Amenities: An Overview of Theory and Concepts," in Gary P. Green, Steven Deller, and David Marcouiller, eds., Amenities and Rural Development: Theory, Methods and Public Policy. Edward Elgar: Northampton, MA, 63-77.

Rosentraub, Mark S. (2009) Major League Winners: Using Sports and Cultural Centers as Tools for Economic Development. CRC Press: Boca Raton, FL.

Sanders, Heywood T. (2002) "Convention Myths and Markets: A Critical Review of Convention Center Feasibility Studies,” Economic Development Quarterly, 16, 195-210.

Shirley, Chad and Clifford Winston. (2004) "Firm Inventory Behavior and the Returns from Highway Infrastructure Investments," Journal of Urban Economics, 55, 398-415.

Siegfried, John and Andrew Zimbalist. (2002) "A Note on the Local Economic Impact of Sports Expenditures," Journal of Sports Economics, 3, 361-366.

Swindell, David and Mark S. Rosentraub. (1998) "Who Benefits from the Presence of Professional Sports Teams? The Implications for Public Funding of Stadiums and Arenas," Public Administration Review, 57, 11-20.

Thompson, Samuel. (2011) "Simple Formulas for Standard Errors That Cluster by Both Firm and Time," Journal of Financial Economics, 99, 1-10.

Tiebout, Charles. (1956) “A Pure Theory of Local Public Expenditure,” Journal of Political Economy, 64, 416-424.

Wheeler, Christopher H. (2001) "A Note on the Spatial Correlation Structure of County-Level Growth in the U.S.," Journal of Regional Science, 41, 433-449.

Wojan, Timothy, Dayton M. Lambert, and David A. McGranahan. (2007) "Emoting with their feet: Bohemian attraction to creative milieu," Journal of Economic Geography, 7, 611726.

Zax, Jeffrey S. (1988) "The Effects of Jurisdiction Types and Numbers on Local Public Finance," in Harvey S. Rosen, ed., Fiscal Federalism: Quantitative Studies. University of Chicago Press: Chicago, 79-106.

Zodrow, George R. (2006) "The Property Tax Incidence Debate and the Mix of State and Local Finance of Local Public Expenditures," CESifo Economic Studies, 53, 495-521.

Zodrow, George R. and Peter Mieszkowski. (1986) "Pigou, Tiebout, Property Taxation, and the Underprovision of Local Public Goods," Journal of Urban Economics, 19, 356-370.

(C) Southern Regional Science Association 2014. 